\title{
Impacts of increased winter snow cover on upland tundra vegetation: a case example
}

\author{
Peter A. Scott ${ }^{1}$, Wayne R. Rouse ${ }^{2}$ \\ ${ }^{1}$ Atmospheric Environment Service, Centre for Atmospheric Research Experiments, RR 1, Egbert, Ontario, Canada L0L 1N0 \\ ${ }^{2}$ Department of Geography, McMaster University, Hamilton, Ontario, Canada L8S 4K1
}

\begin{abstract}
The erection of a snow fence on upland tundra caused a significant change of the vegetation over 11 yr. Compared to nearby exposed tundra, the presence of the snow fence resulted in a warmer soil in winter and a moister and cooler soil in summer. Moisture-intolerant species such as Cetraria nivalis and C. cuculata disappeared completely or decreased in frequency, whereas the more moisture-tolerant species such as Vaccinium uliginosum and Arctostaphylos alpina increased in frequency or established at the site. In terms of climate, any change that promotes a greater winter snowfall, which is the case for warming scenarios in general circulation models, would initiate a relatively rapid change in species composition on upland tundra, particularly if accompanied by increased summer rainfall.
\end{abstract}

KEY WORDS: Climate change - Snow - Tundra vegetation

\section{INTRODUCTION}

Predictions of the effects of global warming on northern environments should include changes in the pattern of snowfall and the total annual snow quantity (Payette et al. 1989). The effects of changes in snow cover greatly influence both terrestrial (Pruitt 1978) and aquatic environments (Adams \& Roulet 1980) and affect winter survival of animals and plants (Pruitt 1978). In particular, tree form and distribution can greatly influence snow re-distribution leading to changes in the environmental conditions (e.g. Payette et al. 1989, Scott et al. 1993) which affect plant and animal distributions. The amount of snow cover is a major variable that contributes to the energy balance of the ground surface which, for example, can lead to frostheaving and palsa development (Seppala 1986). The changing topography influences snow distribution and greatly alters the temperature and moisture conditions of plant communities. Later snowmelt, for example, can delay flowering in plants where flowering is photoperiod dependent (Molau 1993), or result in wetter summer conditions (Rouse 1984).

We examined the impacts of a long-term increase in the snow cover over upland tundra induced by a snow fence. This paper gives the results of the 2 vegetation surveys that were separated by $11 \mathrm{yr}$. We examine the weather characteristics during the 13 yr the snow fence was intact and consider possible causes for the substantial changes in vegetation that occurred during the period.

\section{UPLAND TUNDRA}

The upland tundra communities near Churchill, Manitoba, Canada $\left(58^{\circ} 45^{\prime} \mathrm{N}, 94^{\circ} 04^{\prime} \mathrm{W}\right)$ begin to develop on sand and gravel sediments that have emerged from Hudson Bay (Ritchie 1957). Initially, the sands are colonized by Arenaria peploides and Elymus arenarius [note: vascular plant and lichen nomenclature follows Porsild \& Cody (1980) and Thomson (1984) respectively]. Later the vegetation community is dominated by Carex rupestris and lesser amounts of Dryas integrifolia, Arctostaphylos alpina, Hedysarum mackenzii, Rhododendron Iapponicum and Cetraria nivalis. After the sediments become stabilized, a complex 'climax' lichen-heath tundra community containing many species develops in association with accumulating fibric peat (Shelford \& Twomey 1941, Ritchie 1956, Scoggan 1959, Scott \& Hansell 1989). 


\section{METHODS}

In the summer of 1978 a double-ringed snow fence was erected on upland tundra $14 \mathrm{~km}$ east of Churchill. The snow fence was the commercial type comprising wooden slats to $1.3 \mathrm{~m}$ in height. It was staked in a double ring configuration with the inner ring $8 \mathrm{~m}$ in diameter and the outer ring $13 \mathrm{~m}$ in diameter. In the subsequent winter, snow depths and densities were monitored and in the succeeding summer, detailed soil moisture and soil temperature measurements were made within the snow fence and on the adjacent tundra. Detailed methods of measurement are outlined in Rouse (1982). During late August 1981, the vegetation frequency and cover was estimated on the ground within the inner snow fence and at a control site approximately 50 m east of the fence. At each location 100 quadrats, $10 \times 10 \mathrm{~cm}$ each, were thrown at random. Shoot frequencies were established by recording presence or absence in 9 subdivisions $(3 \times 3)$ within each quadrat. Although no subsequent detailed measurements were made, the site was visited annually until fall 1991 when the snow fence was removed. During late August 1992, the frequency estimates were repeated for both the control and the snow fence sites.

\section{RESULTS}

\section{Measured impacts of the snow fence}

In late winter 1978-79, the maximum depth of snow within the snow fence averaged $1.10 \mathrm{~m}$ which compared to $0.05 \mathrm{~m}$ on the adjacent tundra, $1.40 \mathrm{~m}$ in a nearby open spruce forest and $0.35 \mathrm{~m}$ at the Churchill airport. Although snow depths in the snow fence enclosure corresponded more closely to those of the open forest, the rates of melt were more closely aligned to those of the adjacent tundra. Final snow melt in the enclosure lagged the tundra by only $5 \mathrm{~d}$ in spring 1979 .

In 1978-79 there was more snow than average and the snow cover persisted for $10 \mathrm{~d}$ longer than the average (see Table 1). The snow had accumulated to the top of the snow fence and it is a safe assumption that such depths occurred each year during the $13 \mathrm{yr}$ in which the fence was in place, because in all years, there was at least $0.43 \mathrm{~m}$ of snow measured at the Churchill airport at some time during the winter. The low density of tundra snow and the high wind speeds on the upland tundra ensured that the snow fence entrapped snow to its full height. Visual observations indicated that the snow depth in spring normally exceeded the height of the fence in the inner ring and deep snow overflowed onto the adjacent tundra on the downwind (south) side of the fence. The effects of the latter were evident on the vegetation as discussed later

The primary winter effect of the snow was to maintain much warmer soil temperatures in the enclosure.

Table 1. Snow cover, precipitation and temperature near Churchill Manitoba. Canada

\section{Snow cover}

Period $1955-1993, \mathrm{n}=38 \mathrm{yr}$

Average length of snow cover (Oct 20-May 24) 216

Extreme minimum length $(1971-72$, Nov 11-May 11$) \quad 181 \mathrm{~d}$

Extreme maximum length (1987-88, Oct 8-Jun 10) $245 \mathrm{~d}$

Average depth during average snow season

Extreme minimum depth (at max.) (1971-72)

Extreme maximum depth (at max.) (1955-56)

$91 \mathrm{~cm}$

Period $1978-1991, \mathrm{n}=13 \mathrm{yr}$

Average length of snow cover (Oct 15-May 23)

$220 \mathrm{~d}$

Extreme minimum length (1983-84, Oct 27-May 17)

Extreme maximum length (1987-88, Oct 8-Jun 10)

Average depth during average snow season

Extreme minimum depth (at max.) (1985-86)

Extreme maximum depth (at max.) (1982-83)

202

$246 \mathrm{~d}$

$24 \mathrm{~cm}$

$23 \mathrm{~cm}$

$81 \mathrm{~cm}$

Year 1978-79

Length of snow cover (Oct 15-May 23)

Average depth

$226 \mathrm{~d}$

$37 \mathrm{~cm}$

Precipitation ( $\mathrm{mm}$ )

Period 1943-1992, $\mathrm{n}=50 \mathrm{yr}$

Average annual precipitation

Average rainfall during snow-free period

Period 1978-1991, $\mathrm{n}=13$ yr

Average annual precipitation

Average rainfall during snow-free period

Year $1978-79$

Annual precipitation

Rainfall during snow-free period

Temperature $\left({ }^{\circ} \mathrm{C}\right)$

Period 1943-1992, $\mathrm{n}=50$ yr

Average annual temperature

Average temperature during snow-free period

Average temperature during snow period

Period 1978-1991, $\mathrm{n}=13 \mathrm{yr}$

Average annual temperature

Average temperature during snow-free period

Average temperature during snow period

Year $1978-79$

Annual temperature

Average temperature during snow-free period Average temperature during snow period 


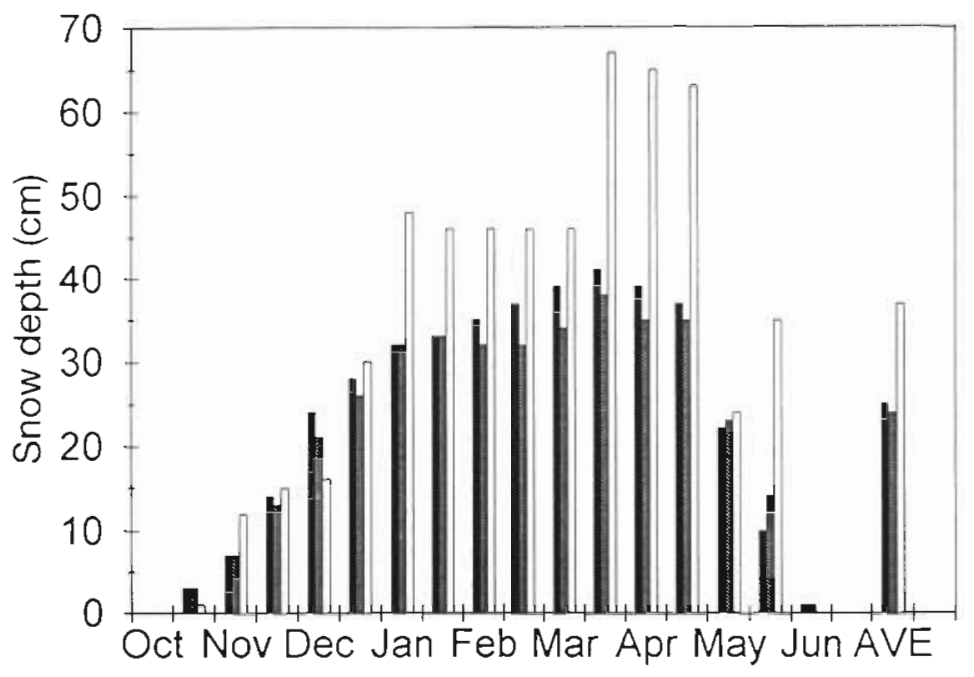

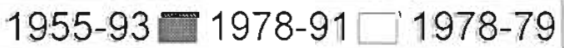

Fig. 1. Snow cover at Churchill showing long-term mean (1955-1993), study period average (1978-1991) and the detailed study year (1978-79). AVE: average for Oct-Jun in the specified period. Data from Rouse (1982) and Atmospheric Environment Service (AES)

\section{Weather conditions during the study period}

Table 1 and Figs. 1 to 3 allow a comparison of snow cover, precipitation and temperature for the detailed study year of $1978-79$, and the study period of 1978-1991 with the long-term means for those climate variables, including data from 1943-1993 when available.

The detailed study year had greater snow depths than those for the full study period or the long-term mean, particularly in the late winter period, and, as noted above, the snow cover during 1978-79 persisted for $10 \mathrm{~d}$ longer than the long-term mean. Averages and seasonal patterns for those climatic variables measured over the 12 yr were very similar to the long-term mean and, in particular, the snow cover lasted only 4 d longer on average.

Although the late winter snow depths in 1978-79 were greater than the long-term mean, the total winter precipitation as measured at the meteorological station was less

By late winter, during persistent subfreezing air temperatures, soil temperatures were not colder than $-1^{\circ} \mathrm{C}$ at all depths from the surface to $2 \mathrm{~m}$, whereas in the adjacent tundra, they were as cold as $-5^{\circ} \mathrm{C}$. The carry-over effects of the snow during the summer period were as follows. The length of the frost-free period in the soil rooting zone was reduced by $16 \mathrm{~d}(12 \%)$ compared to adjacent tundra. This was attributed primarily to the fact that the soil was so wet after final melt that most of the available radiant energy was used in evaporation as opposed to thawing soil. The rooting zone adjacent the snow fence during the growing season was much wetter, with a volumetric moisture 3 times as great as that in the nearby tundra early in the growing season. On average for the growing season, volumetric soil moisture in the snow fence enclosure was $20 \%$ compared to $12 \%$ on the tundra. During freezeback in early winter 1979 (October and November) soil temperatures in the rooting zone of the enclosure were only one-half as cold (relative to $0^{\circ} \mathrm{C}$ ) as that in tundra.

In summary, when compared to the open tundra for the period 1978-79, the snowfenced area had much warmer soils in winter and in summer much wetter and somewhat cooler soils in the rooting zone.

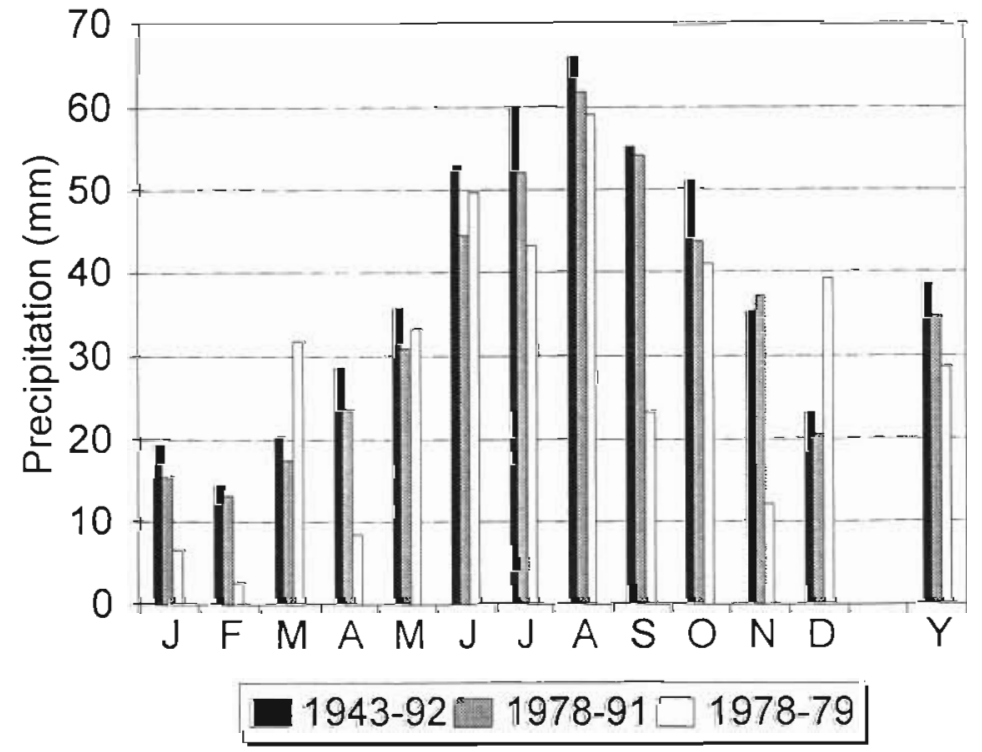

Fig. 2. Precipitation at Churchill showing long-term mean (1943-1993), study period average (1978-1991) and the detailed study year (1978-79). $Y$ : annual average over the specified period. Data from Rouse (1982) and Atmospheric Environment Service (A.ES) than the long-term mean. During the summer it was very similar to the long-term average. For the $12 \mathrm{yr}$ study period, the precipitation in winter was $9 \%$ greater and in summer $16 \%$ greater than the longterm mean. 


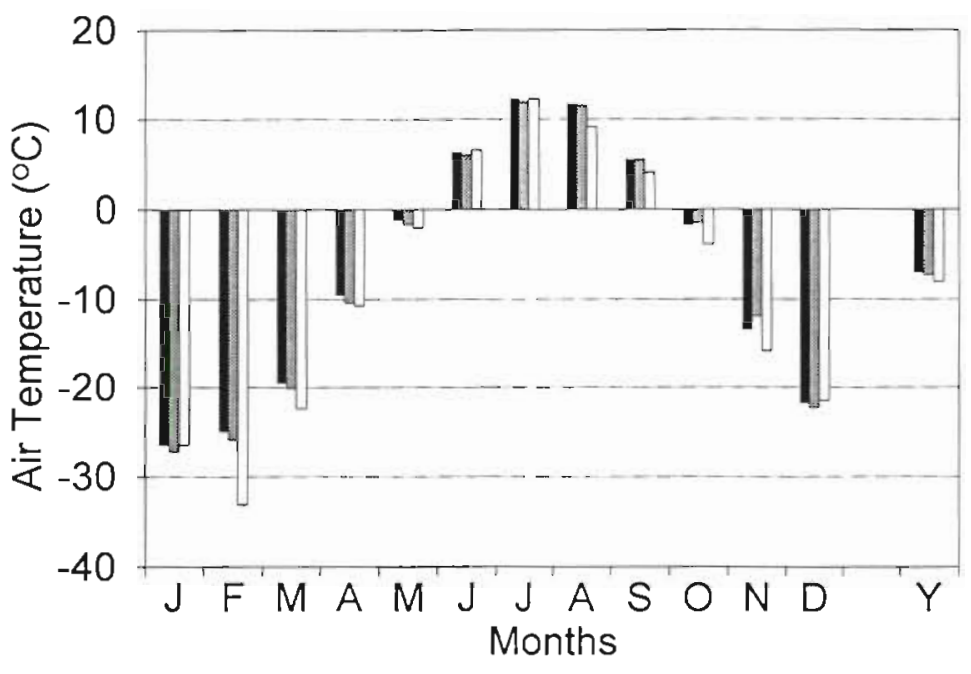

$1943-92 \square 1978-91 \square 1978-79$

Fig. 3. Air temperature at Churchill showing long-term mean (1943-1993), study period average (1978-1991) and the detailed study year (1978-79). Y: annual average over the specified period. Data from Rouse (1982) and Atmospheric Environment Service (AES)

The year $1978-79$ was about $4^{\circ} \mathrm{C}$ colder than the long-term mean temperature during the snow season, but in the snow-free season, air temperatures were the same. The study period was almost $3^{\circ} \mathrm{C}$ colder than the long-term mean temperature in the snow season but also about the same in the snow-free period.

Overall neither 1978-79 nor the study period departed radically from the long-term mean, and we conclude that conditions during both $1978-79$ and the study period were representative of average conditions in this environment. We conclude that the main differential influence was due to the deep snow pack imposed on upland tundra by the snow fence enclosure. This influence was manifested by warmer soils in winter, wetter and somewhat cooler soils in the growing season and a shorter frost-free period in comparison with the unmanipulated tundra.

\section{Vegetation changes}

In the survey in 1981, in addition to generic 'moss and bare ground categories, there were 7 to 8 species of similar frequency (Fig. 4). Both sites had major representations of Carex rupestris, Dryas integrifolia and bare ground (patches of sand). Only the vegetation community within the snow fence contained $C$. scirpoidea and Cladonia stellaris. Cetraria nivalis was most frequent outside the snow fence ( $22 \mathrm{vs} 10 \%)$. Of the species found at both sites, there were no significant differences in frequency evident $(p>0.05)$ from comparisons ( $t$-tests) applied after angular transformation of the data (Zar 1984).

In the survey in 1992 all of the lichen species and Rhododendron lapponicum had died in the area of the snow fences and for $1 \mathrm{~m}$ beyond the $\mathrm{N}, \mathrm{E}$, and $\mathrm{W}$ sides and $7 \mathrm{~m}$ beyond the $S$ side (downwind of winter storms) of the outer fence (Figs. 4 \& 5). Carex rupestris inside the snow fence declined in frequency to approximately a third of that in 1981 while at the control site it was within $75 \%$ of the original frequency. C. scirpoidea declined to one-half its original frequency inside the snow fence while it increased at the control site during the same period. Dryas integrifolia doubled in frequency inside the snow fence and increased slightly at the control site. Arctostaphylos alpina and Vaccinium uliginosum both established and increased in frequency inside the snow fence during this period, reaching frequencies of 13 and $8 \%$ respectively. Overall, there was a reduction from 8 to 6 species inside the snow fence while there was an increase from 7 to 8 species at the control site over the study period. Of the species common to both sites, there was a high variability in occurrence and consequently no significant differences between the species frequencies $(t$ tests of transformed data; $p>0.05$ ).

\section{DISCUSSION}

The vegetation changes in the control plot over the study period appear independent of trends in soil moisture and temperature (Fig. 4). The different species present show a range of moisture preferences as indicated by their distributions around Churchill (Ritchie 1956, Johnson 1987) and other areas (e.g. Svoboda 1977). The frequency of Carex rupestris declined and this species was replaced by $C$. scirpoidea. The increases in frequencies of Rhododendron lapponicum and Cetraria nivalis are an indication of the consistent low winter snow cover at the site. The lichens in particular are known to be most abundant in severe snowfree environments where vascular plants cannot survive (Koerner 1980, Kershaw 1985, Kappen 1993).

The vegetation study represents a single plot and consequently, is not well replicated. However, the results were substantial. Inside the snow fence with the additional snow, all of the species whose habitat in the Churchill region is associated with snow-free and very dry conditions disappeared (i.e. Cladonia stellaris, Cetraria nivalis, C. cuculata, and Rhododendron lapponicum). Both upland sedges (Carex rupestris and $C$. 

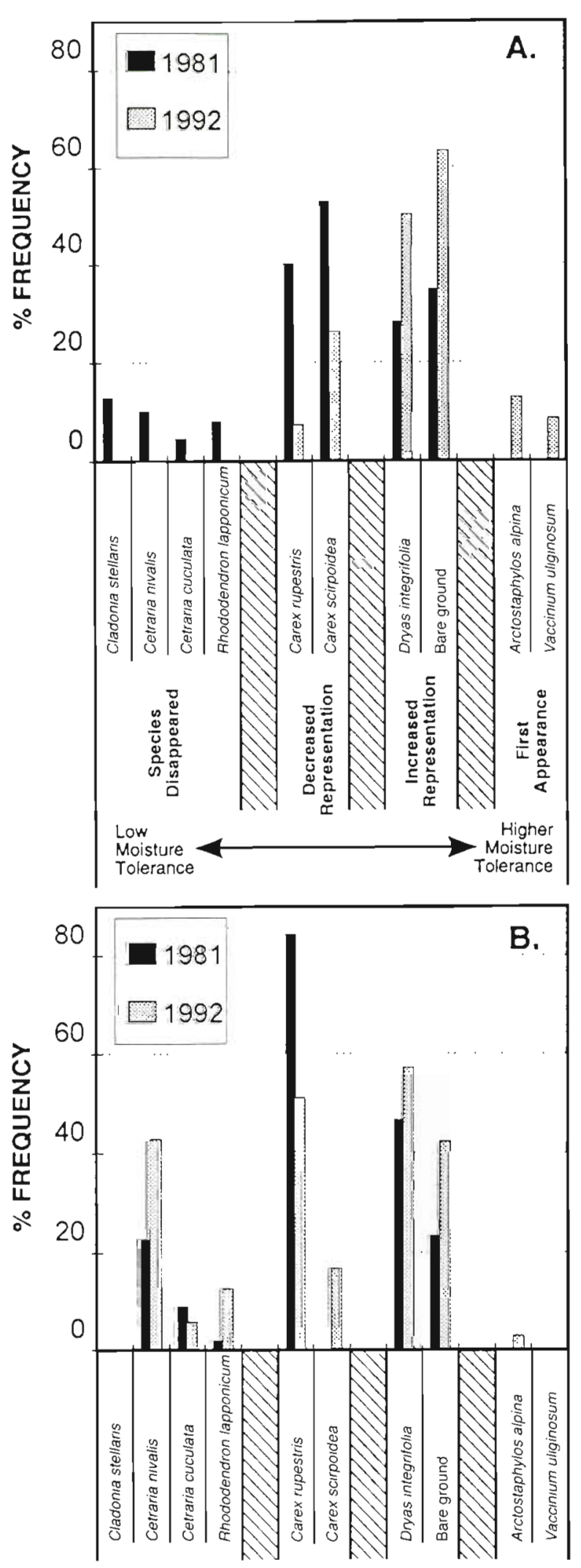

Fig. 4. Vegetation frequency at (A) the snow fence and $(B)$ the control sites for 1981 and 1992

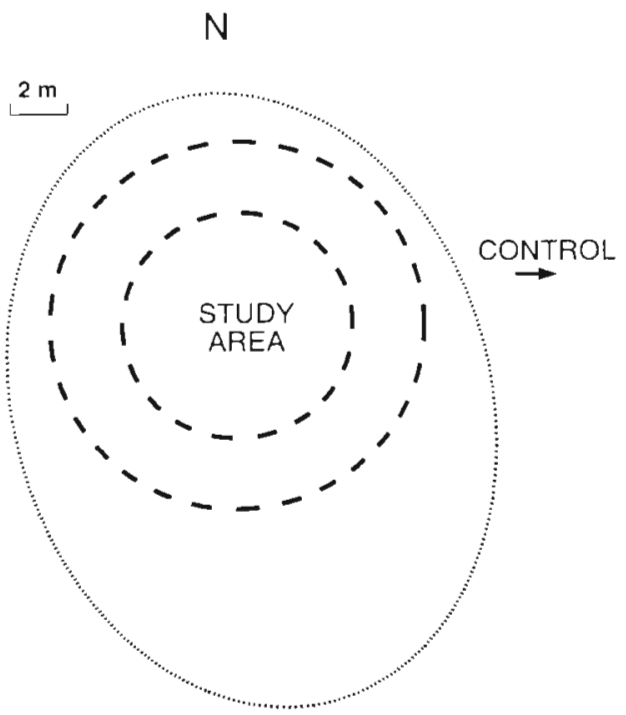

Fig. 5. Snow-fence and control plots showing configuration of snow fences (dashed lines) and the area in which all lichens died off (dotted line)

scirpoidea) declined sharply in frequency and bare ground increased in coincidence with the decline and disappearance of moisture-intolerant plants. At the opposite end of the scale, species more tolerant of moist conditions (e.g. Arctostaphylos alpina and Vaccinium uliginosum) established. Many such species are mat forming (i.e. A. alpina and Dryas integrifolia) and consequently, in association with their increase in frequency, there was a change in the distribution of the vegetation from more dispersed to clumped. Further, many of these species produce large deciduous leaves which contribute significantly to litter accumulation, peat development and nutrient availability (Babb \& Whitfield 1977, Svoboda 1977). The transition from the species-poor plant community that develops on sands and gravels of elevated beach deposits, to peaty lichen-heath begins after gradual stabilization of the dune which enables extensive colonization by the slow-growing $D$. integrifolia (Muc \& Bliss 1977). The developing mats of $D$. integrifolia form a thin peat layer over the sand that retains water and thereby changes the thermal and moisture conditions at the soil surface, which facilitates the development of lichenheath.

There is thus a strong association apparent between the changing moisture condition and change in plant species which was brought about by an increase in the volume of winter snow cover. Although it does not lead to a substantial change in the date of melt (only $5 \mathrm{~d}$ later), the increased snow pack does raise the soil temperature in winter and leads to wetter and somewhat cooler soil, with a shorter frost-free season in summer. 
We speculate that the altered physical environment during the growing season may stimulate the changes in the vegetation community. This is in keeping with Koerner (1980) who hypothesized that the shorter growing season associated with seasonal snow fields in the high arctic is likely to result in exclusion of lichens. The much deeper snow cover in winter can greatly reduce solar irradiation and gaseous exchange between organisms and the environment. For example, because $\mathrm{CO}_{2}$ diffuses poorly through snow (Penny \& Pruitt 1984), photosynthesis of lichens in winter would be inhibited (Kappen 1993). Respiration studies reveal that Cetraria nivalis, for example, is continuously acclimatizing to ambient temperature (Kershaw 1985). The additional snow cover might interfere with the acclimatization process which would explain the loss of lichens under these conditions.

The implications of this study with respect to possible climate change are important. Any change that promotes higher winter snowfall will have a pronounced effect on vegetation communities even if summer precipitation and temperature remain unchanged. Given climate warming scenarios which predict warmer winters with a resulting heavier winter precipitation this is a very real possibility. If this is accompanied by wetter summers, changes in the vegetation composition are likely to proceed rapidly.

Acknowledgements. Assistance in the field was provided by D. Holmes and I. Craine. Snow accumulation data from the Churchill airport was provided by the Churchill Weather Office and the Atmospheric Environment Service, 4905 Dufferin St., Downsview, Ontario, Canada. Support was provided by Atmospheric Environment Service, Canada

\section{LITERATURE CITED}

Adams WP, Roulet NT (1980) Illustration of the roles of snow in the evolution of the winter cover of a lake. Arctic 33: $100-116$

Babb TA, Whitfield DWA (1977) Mineral nutrient cycling and limitation of plant growth in the Truelove Lowland ecosystem. In: Bliss LC (ed) Truelove Lowland, Devon Island, Canada: a high arctic ecosystem. University of Alberta Press, Edmonton, p 589-596

Johnson KL (1987) Wildflowers of Churchill and the Hudson
Bay region. Manitoba Museum of Man and Nature, Winnipeg

Kappen L (1993) Plant activity under snow and ice with particular reference to lichens. Arctic 46:297-302

Kershaw KA (1985) Physiological ecology of lichens. Cambridge University Press, New York

Koerner RM (1980) The problem of lichen-free zones in Arctic Canada. Arc Alp Res 12:87-94

Molau U (1993) Relationships between flowering phenology and life history strategies in tundra plants. Arct alp Res 25:391-402

Muc M, Bliss LC (1977) Plant communities of Truelove Lowland. In: Bliss LC (ed) Truelove Lowland, Devon Island, Canada: a high arctic ecosystem. University of Alberta Press, Edmonton, p 143-154

Payette S, Filion L, Delwaide A, Bégin C (1989) Reconstruction of tree-line vegetation response to long-term climate change. Nature 341:429-432

Penny CE, Pruitt WO (1984) Subnivean accumulations of $\mathrm{CO}_{2}$ and its effect on winter distribution of small mammals. Carnegie Mus nat Hist Spec Publ 10:373-380

Porsild AE, Cody WJ (1980) Vascular plants of continental Northwest Territories, Canada. National Museums of Canada, Ottawa

Pruitt WO (1978) Boreal ecology. Edward Arnold, London

Ritchie JC (1956) The native plants of Churchill, Manitoba, Canada. Can J Bot 34:269-320

Ritchie JC (1957) The vegetation of northern Manitoba. II. A prisere on the Hudson Bay Lowlands. Ecology 38:429-435

Rouse WR (1982) Microclimate of low arctic tundra and forest at Churchill, Manitoba. In: Proc 4th Can Permafrost Conf, National Research Council, Ottawa, p 68-80

Rouse WR (1984) Microclimate of the arctic treeline 2. Soil microclimate of tundra and forest. Water Resour Res 20: $67-73$

Scoggan HJ (1959) The native flora of Churchill, Manitoba National Museum of Canada, Ottawa

Scott PA, Hansell RIC (1989) The lemming community on the lichen-heath tundra at Churchill, Manitoba. Can FieldNat 103:358-362

Scott PA, Hansell RIC, Erickson WR (1993) Influences of wind and snow on northern treeline environments at Churchill, Manitoba, Canada. Arctic 46:316-323

Seppala M (1986) The origin of palsas. Geografiska Annaler 68A: $141-147$

Shelford VC, Twomey AC (1941) Tundra animal communities in the vicinity of Churchill, Manitoba. Ecology 22:47-69

Svoboda J (1977) Ecology and primary production of raised beach communities, Truelove Lowland. In: Bliss LC (ed) Truelove Lowland, Devon Island, Canada: a high arctic ecosystem. University of Alberta Press, Edmonton, p 185-216

Thomson JW (1984) American Arctic lichens 1. The macrolichens. Columbia University Press, New York

Zar JH (1984) Biostatistical analysis, 2nd edn. Prentice Hall, Englewood Cliffs, $\mathrm{NJ}$ 